\title{
dossier ALTERITY, OTHERNESS AND JOURNALISM: \\ from phenomenology to narration of modes of existence
}

Copyright (C) 2017 SBPjor / Associação Brasileira de Pesquisadores em Jornalismo

\section{CAMILA FREITAS}

Universidade Federal do Rio Grande do Sul, Brazil

MARCIA BENETTI

Universidade Federal do Rio Grande do Sul, Brazil

DOI: http://dx.doi.org/10.25200/BJR.v13n2.2017.989

\begin{abstract}
In a theoretical reflection, the aim of this paper is primarily to discuss alterity in journalism. We believe that journalism plays a fundamental role in the construction of knowledge on similarities and differences between human beings, stressing social diversity as one of its purposes. We associate the concept of otherness, understood as a singular mode of existence of the "other", with the purpose of journalism and with actions of empathy, sympathy and compassion. Based on a phenomenological perspective, we discuss the importance of the meeting between the "self" and the "other", as well as the ability of journalists to perceive and narrate on the aspects that shape the identities of human beings. Moreover, we discuss otherness in journalistic narratives, approaching the relation between the lifeworld and the world of text, taking into consideration the elements of perception, mimesis, textuality and interpretation.
\end{abstract}

Key words: Alterity. Otherness. Journalism. Narrative. Phenomenon.

\section{ALTERIDADE, OUTRIDADE E JORNALISMO: do fenômeno à narração do modo de existência}

RESUMO - Este artigo tem caráter teórico e visa discutir a alteridade no jornalismo. Consideramos que o jornalismo tem um papel fundamental na construção do conhecimento sobre as semelhanças e as diferenças entre os seres humanos, sendo a apresentação da diversidade social uma de suas finalidades. Propomos associar o conceito de outridade, compreendida como o modo de existência do "outro" em sua singularidade, a essa finalidade do jornalismo e a ações de empatia, simpatia e compaixão. Adotamos uma perspectiva fenomenológica, indicando a relevância da experiência do encontro entre o "eu" e o "outro" e a capacidade de o jornalista perceber e narrar os aspectos que configuram as múltiplas identidades dos seres. Tratamos ainda da outridade na narrativa jornalística, abordando a relação entre o mundo da vida e o mundo do texto e discutindo os princípios da percepção, da ação mimética, da textualidade e da interpretação.

Palavras-chave: Alteridade. Outridade. Jornalismo. Narrativa. Fenômeno. 


\section{ALTERIDAD, OTREDAD Y PERIODISMO: del fenómeno a la narración del modo de existencia}

RESUMEN - Este artículo de carácter teórico analiza la alteridad en el periodismo. Creemos que el periodismo tiene un papel fundamental en la construcción de los saberes acerca de las similitudes y diferencias entre los seres humanos, una vez que la presentación de la diversidad social és uno de sus propósitos. Combinamos el concepto de otredad, que se entiende como el modo de existencia del "otro" en su singularidad, con la finalidad del periodismo. Adoptamos un punto de vista fenomenológico, lo que indica la importancia de la experiencia del encuentro entre "yo" y "otro" y la capacidad del periodista para percibir y narrar características de las múltiples identidades de los seres. También trabajamos con la otredad en la narrativa periodista, presentando la relación entre el mundo de la vida y el mundo del texto, así tratando de los principios de la percepción, de la acción mimética, de la textualidad y de la interpretación.

Palabras clave: Alteridad. Otredad. Periodismo. Narrativa. Fenómeno.

\section{Introduction}

Journalism is an activity committed to observing and narrating on notable events (Cornu, 1999) from phenomena to facts, all of which exist in the world previous to any narrative intervention. Focused on social diversity, it is journalism's ability to narrate a phenomena and reconstruct it singularly in text that helps us understand the times we live in and the people who live in them. This mediating ability - to relate life through text - means that journalism plays a fundamental role in building knowledge on the differences and similarities among human beings (Karam, 1997). It is the focus on perception and experience of the "self-subject-journalist/vehicle" before the "otherssubjects" that explains, through narrative, the mode of existence of the perceived subjects. We agree with Lago $(2014$, p. 175) when she says that "journalism has a moral obligation to present the multiple opinions of society", and with Reginato (2016, p. 230), who believes that journalism has a responsibility to show social diversity and "the important structural dissimilarities between different groups". We believe that recognizing alterity should be one of the principles of journalists, or one of their duties.

Alterity is not a new topic. Many researchers (Arendt, 2009; Barbosa, 2008; Dionizio, 2011; Benetti \& Freitas, 2015; Buber, 1986; 
Charaudeau, 1991; Costa, 2010; Gomes, 2012; Hazell, 2009; Jodelet, 1998; Lago, 2014; Lévinas, 1987; 1999; 2010; Resende, 2014; Marcondes Filho, 2016; Martino, 2016; Peres, 2016; Prado \& Bairon, 2007; Ricoeur, 2006; 2008; 2014; Sodré, 2007; Treanor, 2006) are engaged in discussing alterity and raising questions on the identity, visibility, representation, disappearance, sameness and apprehension of the "other". In this paper, we think of alterity from the concept of otherness, the mode of existence which articulates the "self" with the identity of the other.

We shall discuss building the identity of the "other" in journalism by looking at the theory behind alterity, otherness and journalism. We will reflect on alterity as a phenomenon, otherness as a mode of existence, and the ability of journalism to articulate life through text.

\section{Alterity as a phenomenon}

Studies on phenomenology (Husserl, 1982; Merleau-Ponty, 2011 ; 1968; Lévinas, 1971 , 1982; 1987; 1999) approach the problems of being and the world by describing the physical and conscious experiences the subject has with the world. Phenomenological thinking is composed of three parts: the mind, the body and the world, which help to understand alterity as a phenomenon which occurs in the world, in the spirit-body and between the "self" and the "other". You can think of a phenomenon as the primary manifestation of all that can be perceived, and through this perception we are able to access the world we live in (Merleau-Ponty, 2011). This perception provides a "universe" of defined and situated things for the subject (Romdenh-Romluc, 2011). So, perception is the actual meeting place of subjectivity between the "self" and the world.

We see the world as a phenomenological field of experience (Merleau-Ponty, 2011 ). With any experience, the subject who does the experiencing is in the world. Thinking and living are inseparable from one another because the world and consciousness have a mutual relationship, revealing an incarnate conscience or embodied subject. The subject cannot be separated from the world because the body reveals the subject in the world.

Unifying action and existence, the body is an intimate and unique unit of the subject - it is a self (consciousness) and $a$ whole 
(physical object). The body is a "junction between essence and existence which we rediscover through perception" (Merleau-Ponty, 2011 , p. 204). This means that the subject, more than just living "in a world of conscious states or representations" (Merleau-Ponty, 1968 , p. 204, our translation'), lives in a world of phenomena and experiences, directly linked "with beings, things and its own body" (Merleau-Ponty, 1968, p. 204, our translation ${ }^{2}$ ). And it is through facticity - the concrete existence of the subject in the world - that we are able to understand the relationship between consciousness, body and the world, which gives us the idea of self in the world.

Let's consider that every subject has the ability to perceive (consciously and physically) the world in which it lives and, as a consequence, this subject understands what manifests in front of it - and what it experiences - is conditioned by a personal idea of truth. This means that knowledge about things or people is variable and that we will have a variety of points of view about the same subject or object. It is not hard to see that a perceived phenomenon leads to an interpretation of a personal truth, in such a way that the truth becomes unique for every self due to their perception of it. In this case, as human beings living in a complex world of time and space, we tend to reduce the world to our experiences in order to explain and understand not only ourselves, but the others who we live with. There are two issues here when this dynamic is applied to journalism. The first one is that a reporter is also a self in the world who experiences phenomena and its own contact with the "other". Yet, because reporters find themselves in a specific discursive place, they organize their experiences based on not just their own expectations but on shared knowledge of how a reporter should deal with that which is different from him or her. The second issue is journalism, or journalism as an institution, which tries to expand the knowledge of its audience. This requires stimulating the audience and not reducing the world to their own universe of experiences.

The notion of coexistence surpasses the unique individuality of the self, expressing it as a relational subject and transforming it into a self in the world of the other. Therefore, every subjectivity manifests as a phenomenon of knowledge. In the dialectic of the "self" and the "other", both should be preserved in their facticity as it is necessary to have "not only a perspective of The Whole - my view of myself and the other's view of himself - but a perspective of The Other - my view of the Other and the Other's view of me" 
(Merleau-Ponty, 2011 , p. 8). If alterity is the premise for coexistence, then the relationship between the subject and others is affected by many types of existence and can act in the world as a being through the "intersection of my experiences and the intersection of my experiences with those of the other" (Merleau-Ponty, 2011, p. 18). There is an interlacing sustained by the difference which requires knowledge of a certain similitude ${ }^{3}$, of something that is shared:

Difference and alterity are truly experienced only by an openness that recognizes that despite all of the undoubted differences that we encounter, there is always something shared that allows difference to be conceivable at all. This is an effort not to reintegrate difference into sameness, but to transform the notions of self and other in any attempt to behave responsibly toward the alterity of the other.

If alterity is seen here as a phenomenon involving the "self" and the "other" in an interdependant relationship in the world then otherness is what explains the mode of existence of the "other" to the "self".

\section{Otherness as a mode of existence}

Most often, meeting the "other" brings on feelings of anxiety or strangeness because Western point of view has traditionally thought of the identity of the "other" as something to be conquered (Treanor, 2006). In order to dominate or conquer something one must shape the different into structures that are already familiar, this way the different is prevented from expressing its characteristics, its special qualities and its original form of existence, in other words, its otherness. This promotes a relationship of verification between the "self" and the "other" (Treanor, 2006) because what is unknown to us is immediately compared to what is normal, customary or common. The "other" is expected to fit in to what is already accepted, conditioning its singularity to disappearance in order that this "other" becomes identical or a "same". The problem is in the juxtaposition or level of identities, which suppress the differences of subjects in relationship and prioritizes sameness - the pairing of identities from the "self" and the "other".

We know there could be similarities between subjects and, in a certain way, this brings us closer. Arendt (2009) points out that if humans were not "equal" as a species, they would not be capable 
of understanding one another or of planning for the future. And if they were not different in their characteristics "they would not need discourse or action in order to understand one another" (Arendt, 2009, p. 200, our translation ${ }^{4}$ ). Here, neither difference nor similarity cancel each other out, which leads us to believe that recognizing the "other" has much to do with our willingness or ability to understand forms of existence different from ours. Treanor (2006) states that otherness is the meeting point between the phenomenon of alterity and similarity. The "other" as similarity appears as something familiar and easy to understand, even though similarity does not mean transparency between "self" and "other", it only reveals what is perceived to be common among them. A phenomenon of alterity is the "the other is that which can reveal or bring about something new and unforeseen" (Treanor, 2006, p. 229), just the same as it can limit any approximation with another subject because it is in itself somewhat ambiguous and unattainable.

So, by the simple fact that "no other we experience or relate to is either completely foreign or perfectly intelligible" (Treanor, 2006, p. 230), similarity and alterity become presuppositions of otherness, culminating in a balance between similarities and differences each time the "self" and the "other" meet. There is always something more than what is perceivable either because it is not easy to understand or because it is not communicated or not expressed physically, thereby making the "other" appear elusive in its totality.

Being present in the world places us between subjects, but it also places us in society - which is an "other" inasmuch as it is a third party to the dynamic of "self" and "other". Society shelters us and confronts us, is demanding and demands responsibility (Lévinas, 1999; Ricoeur, 2008). So, "I am responsible for the other, and we are both responsible for others (thirds), and, indeed, others are responsible for me" (Treanor, 2006, p. 43). This is where the tie between society and responsibility lies with otherness.

In an intersubjective meeting there are possible aspects of apprehension and sometimes there are not. This is because every "other" is for us, both distant and close, sure and unsure, an "other" itself and an "other" open to interpretation. These contradictions are called absolute otherness and relative otherness ${ }^{5}$. Absolute otherness is that which conforms to the interior of the "other" and therefore is not explicit. It is about the "other" as a whole and for itself - it is the "other" in its entirety and intimacy, with its individual 
anxieties, desires, emotions, feelings and perceptions, inaccessable or unrevealed in face to face contact. Absolute otherness does not produce any meeting whatsoever and does not immediately communicate with this "other". On the contrary, everything that it does not reveal allows for suppositions and hypotheses and thereby becomes relative to the otherness of the subject.

If absolute otherness escapes us, relative otherness allows us to reach the knowledge we seek about the "other". It is relative by the fact that it relates singular subjects (mutually) and yet remains ambiguous - the "other" communicates verbally or physically, showing differences and similarities, but within this communication is the silence of absolute otherness. So, absolute otherness is active in intersubjective relationships because it can distinguish between what is perceived and what is supposed. This type of otherness is always open to interpretation (Treanor, 2006) and reinterpretation with each new meeting between the "self" and the "other" or "others".

However, if the knowledge gained about the identity of the "other" comes from perception and interpretation then it is possible that our interpretations are mistaken since interpretation is just as subjective and ambiguous as the intersubjective relationship it originates from. A meeting between subjects is a back and forth movement in an attempt to recognize what it is that is manifested in front of them, which means the interpretation of the other is not of immediate perception, it is aware of itself, it is an ideal "other".

In intersubjective relationships, recognizing the "other" socially, physically or temporally (for example, poverty, illness and old age) might be the result of the emotions and experiences of affection one gets from acts of sympathy, empathy and compassion. These three emotions generate feelings, are related to the phenomenon of alterity and articulate the perspectives of for the self and for the other. When the "other" manifests in conditions similar or different to those in which we currently are or know, we understand it first through our imagination with all its pre-formed values and beliefs as well as our ability to identify and our attempt to put ourselves in the place of the "other". When we rebuild the experience of the "other" - putting ourselves in its position and comparing its experiences to ours - we are able to recognize it in our own way.

Actions of empathy and sympathy are based on the interchange between "self" and "other", in other words, the change of position between them (metaphorically and imaginatively speaking). 
Sympathy is a form of communion or harmony with feelings; it is feeling for the other. Empathy is the ability to understand another person and share what they are feeling; it is feeling with the other (Bubandt \& Willerslev, 2014).

Compassion carries many judgments of values with it depending on the importance or severity of the situation in which a person finds themselves. For example, we have compassion for people who suffer in life from death, victimization, illness, or lack of food, as well as for people who are physically or emotionally weak, as Nussbaum (2001) points out. Perceptions and judgments vary from person to person and have an influence on society, whether culturally, religiously or politically. Concerning relative otherness, it is possible that the interpretation of the "other's" condition of suffering is overestimated, leading towards compassion for a person who does not see themselves as suffering.

While sympathy and compassion are ways of relating with the "other" or of being relative to someone different, empathy is another way of obtaining knowledge about the identity of the subject. It requires approaching and distancing oneself while attempting to mimic and think about what it would be like if the "self" were the "other" (Bubandt \& Willerslev, 2014; Wispé, 1986) in order to identify with the otherness of this subject. Even though the purpose of identifying empathy is to understand the "other" or understanding compassion, it can also identify harmful actions which the otherness mimics in order to manipulate, seduce, mislead, forget or violate the "other" (Bubandt \& Willerslev, 2014).

When it comes to recognizing the "other", we believe the interweaving between time and otherness is important. It brings up memories which helps us interpret not only the "other" but ourselves, encouraging some changes or reaffirming previously identified aspects of society and identity (Benetti \& Freitas, 2015). Within this weaving we have memories, which are representations of a past, and act as subsidiaries towards maintaining the identity of the subject in the face of forgetting (Ricoeur, 2015). Remembering an event can prevent from forgetting certain identities associated with empathy, compassion and sympathy. Even so, studying the subjects and their environment can also to a selective phase where some subjects become perceived and others remain invisible. This is a form for managing the modes of living and ensuring that any choice is a subjective one, reflected in how willing one is to know and deal with otherness. 


\section{Alterity and otherness in journalism}

As we stated earlier, the perception of the world is neither complete nor equal for all. We acquire our knowledge and give meaning to the numerous phenomena that occur throughout our lives through intersubjective relationships. This is not something that occurs on initial contact between a subject and a medium, it is built and mediated in society through actions, perceptions, experiences, and subjective interactions. This is also true for narratives in journalism - they observe, interpret, mimic and organize the social world and the subjects in text while reshaping the phenomenon through singularity (Genro Filho, 1987).

Alterity and otherness have been discussed up to this point as a phenomenon and a mode of existence, respectively. We would now like to expand our knowledge on this and put it in the context of journalism, which articulates the lifeworld with the text using the dynamic in which "the world of the text opens on to the lifeworld [...], and at the same time conversely, through which the lifeworld can be known by an experience of textuality" (Foessel, 2016, p. 76). As Resende (2011, p. 134) says, journalism's goal is "to interlace worlds and weave networks with all their obstacles and power that is there".

It is through mimicking that journalism gets its power to reproduce and reshape what happens in the lifeworld, narrating realities and the multiplicity of beings and things that reside within it, all the while conferring the credibility of daily events. The diegesis of a narrative (the universe of text) contains aspects that compare or correspond to the exegetic universe (the exterior of the text), exposing its credibility towards validating the narrative (Genette, 1995; Traquina, 2012). From this point, we shall look at journalism first, as a type of discourse that evidences alterity, and second, as otherness mimicked and narrated through journalistic activity.

Journalism is defined in the field of discourse as "a form of social relationship established through the use of language" (Meditsch, 2001, p. 1). Intersubjective relationships - of which the discourse itself is dependent on - show that discourse, an effect of meaning, is produced not only by journalists but also by the public whenever they read and interpret. According to Benetti (2007, p. 108), "discourse is, then, opaque, not transparent, full of possible interpretations", referring to the narrator, to the world which sustains him, and to the "others". There is a plurality of voices in the discursive dimension of journalism that wish to communicate and recreate and 
"reproduce knowledge generated by other actors" (Benetti, 2007, p. 110), in this case, not journalists. This polyphony, when it happens, conforms the phenomenon of alterity in journalistic text - every voice is an opportunity to perceive alterity and the dynamic correlation of "self-subject-journalist/vehicle" with "others-subjects".

It is through this logic that we find four mechanisms of meaning for one language act produced by a subject (Charaudeau, 2013). The first mechanism is our hypotheses for clarifying aspects of the identity of the "other", in other words, showing "its knowledge, its social position, its psychological state, its aptitudes, its interests" (Charaudeau, 2013, p. 41). The second is the effects we intend to produce on (or in) this other subject. The third is the level of relationship which allows us to focus on the type of bond we would like to establish with this "other. The fourth mechanism is the type of regulation which is expected from language itself, articulating the three previous mechanisms.

Before even representing the reality of daily life, each discourse is presented as an exchange between subjects, positioning the existence of the identities of "self" and the "other" as the first act of communication. For Charaudeau (2013), it is through speaking about, with and for the "other" which we are able to describe the world in all its complexity. The principle of journalism is exactly about perceiving the "other", making it visible and understandable whether by assimilation (just like a similar) or differentiation of subjects in relation to the narrative (within and outside of the text). Journalism, as a specific discursive gender (Benetti, 2008), is traversed by the phenomenon of alterity.

Clearly, the issue with alterity in journalism is not just about the relationship between subject-enunciator (journalist/vehicle) and subject-interpreter (public). There is a bigger relationship process in which the condition of the "other" is plural. In this case, the "others" are sources, the real readers and the imagined readers, the "others" narrated and idealized by journalistic discourse, the "others" members of the professional community of journalists and, on an organizational level, the "others" vehicles. There is space in journalism for journalists to think about themselves, and demonstrate what is different or similar in relation to the "others", all in order to "be tolerant and correct their behaviour" (Benetti \& Freitas, 2015, p. 175) which can lead to understanding how they (journalists) perceive alterity and narrate otherness.

When we think about alterity under these circumstances, journalists are required to understand the complexity of the society they 
live in by observing and describing it narratively. As we have already mentioned, the worlds of life and text are interdependent on journalism because of the number of perceptions within them. The world of text, which serves as a secondary reference for interpreting the reality of human beings, becomes more than just a narrated universe. It is a place for family and outsiders where similarities and differences in identities and time are uncovered from "synthetic activity that assembles a speaker, a saying, a said, events and, ultimately, a world" (Foessel, 2016, p. 80).

From here we move toward the second condition of alterity in journalism which interconnects three aspects: manifestation of a phenomenon in the living world (the phenomenological dimension), the mode of existence focused on the singularity of a subject (otherness) and the interpretation and understanding of this singular existence in narrative. This brings us to mimicking, which is the collective perception and experience we have of the world, the text and interpretation. For Ricoeur (2010), this collection is organized according to prefiguration, configuration and refiguration of the time dimension of the world from perception to narrative.

Prefiguration refers to the pre-narrated world of perception, phenomena, intersubjectivity - a moment in which the lifeworld "searches" for a narrative action in order to rebuild it as a living experience. Configuration is the scope of the construction of the text. The events within it are spread out chronologically and according to hierarchy using a narrative structure that places events in order of importance. Motta (2013, p. 73) says narratives place "events in perspective, gather items together, put precedents and consequences in order, relate things, create the past, present and future, fit partial meanings to time sequences, explanations and stable meanings" in journalism, configuration is the result of mediation from journalists. Refiguration is the moment when the active presence of the reader reshapes what was narrated. It is an interpretative and perceptive experience where "perception cannot be described in any other way than through the relation that the subject has with the meanings that surround it". (Foessel, 2016, p. 76), referring to an issue, a context or a search for reference (in the reader's world) about what was narrated and what will be interpreted.

A journalistic text written in the present contains gaps ${ }^{6}$ in which the reader is able to project themselves into the textual universe and begin mimicking as a subject that experiences the version of reality which is built. The phenomenon of alterity in this process occurs through the manifestation of at least three identities: 
the journalist (who may also be the narrator of the text), the public and the "other" which has been narrated on. The last one has to do with building the identity of the "other" in journalism.

Accessing the mode of singular existence for the "other" first occurs in the lifeworld. This "other" is both the source and the object of a journalist's discursive narrative. When the "self-subject-journalist" meets the "other-subject-source", the journalist does not have access to absolute otherness, only relative. Journalists mould, interpret and understand the otherness of the "other-source" through immediate contact (perception), the relationship with this subject and through journalistic techniques, the interview being one such technique. Since life experience and identity can be narrated and made into a story using a singular phenomenon, subject actions, time and a structure for the narrative (Ricoeur, 1986; 2014), journalists end up mimicking the otherness of said subject when they narrate the existence of the "other", thereby conditioning this otherness to the construction of narratives and the characteristics of journalistic discourse as a specific field.

Here the identity of the "other" becomes an essential narrative identity that is recreated in text and differs from its original phenomenological state. Even though this identity maintains singular aspects of the subject, it is neither the subject itself (the person expressed) nor the "relative other" which is presented, what is presented is the "other" from and in the text - the ideal "other", mimicked by journalism and manifested as a phenomenon of the text it belongs to. There is an interpretation that the public has here, and when this public reads the text they will come to know the "other" as it is narrated according to the reconfiguration of journalistic events which tends to "dilute" the otherness. There is further mnemonic and affective actions being provoked here, establishing a link between "self-subject-reader" and "other-subject-character".

Reconfiguration by the public opens up the possibility to reinterpret what the journalist had presented. This is because otherness is reduced to stereotypes and typifications in narratives in order to understand and describe it while using memesis to restore the singularity to the narrated subject, registering it in its particular context. We realized that reconstructing the narrative of the otherness is a way to access and understand this subject through traces of its singularity which remain in the text, even though each new hermeneutic action is repeated by the otherness. Thanks to its mimetic ability we are able to say that every otherness in journalism is relative, historicized, interpreted, rebuilt and given new meaning by both the public and journalists. 
Reflecting on alterity and otherness makes journalism pay attention to the plurality that makes up daily life. The discussion in this paper brings together two understandings. The first is that narratives and journalistic discourse allow for the interpreter to judge and be close to what they are presenting, providing access to the identity of journalists and the narrated subjects. The second understanding is the ability which the phenomenon of alterity has of making us perceive the process of time and space mediation for intersubjective relationships (referred to as similarities and differences) in order to further knowledge on the diversity of the world.

\section{Final considerations}

In this paper we have looked at alterity and otherness from a phenomenological perspective, understanding alterity as a phenomenon and otherness as a mode of existence. Phenomenology helps us think of human beings as they are situated in the world in order that perception of the world and everything in it conforms to individual and collective experiences just like the descriptions and interpretations we have of perceived phenomena; to justify our individual truths in the world we live in. It is through one subject's perception of another that each subjectivity is revealed both as an intersubjective experience and a recognizable phenomenon, not excluding the time dimension of coexistence, affective actions (sympathy, empathy and compassion) and memories.

Alterity is understood here as a phenomenon involving the "self" and the "other" interdependently. Otherness is understood here as: a) explaining the original and singular mode of existence of the "other" for the "self" in the world; b) having aspects of both similarity and difference; c) promoting a balance between what is different and similar each time the "self" and the "other" perceive one another and; d) being relative and absolute.

In the scope of journalistic discourse, narratives are forms of accessing social phenomena perceived and mimicked by journalists. In this case, alterity and otherness have a broader reach as the focus of journalism is in perception and experience of the "self-subject-journalist/ vehicle" and the "others-subjects-readers/sources/characters", just like the perception and experience of the "self-subject-reader" and the "others-subjects-journalists/vehicle/sources/characters". 
If we say that the articulation of the lifeworld and the world of text presupposes that alterity shapes discourse and journalistic narratives as well as demonstrates the otherness, we can then conclude that, in journalism, this alterity mobilizes: a) the phenomenological dimension itself; b) the mode of existence of singularity of a subject; c) the interpretation and understanding of singular existence. Using the same logic, articulating perception, mimesis, text and interpretation in journalism means the otherness: a) is relative; b) can be historicized, interpreted, built and given new meaning; c) depends on journalists to call attention to it and on the public to recognize it and; d) encourages affective and mnemonic actions.

*This paper was translated by Lee Sharp

\section{NOTES}

1 Original: "dans un monde d'états de conscience ou de représentations".

2 Original: "avec les êtres, les choses et son propre corps".

3 "Similitude is that aspect of things, and others, that is in some way familiar or understandable”. (TREANOR, 2006, p. 229, tradução nossa).

4 Original: "no necesitarían el discurso ni la acción para entenderse".

5 Treanor (2006) uses the terms absolute otherness (outridade absoluta) and relative otherness (outridade relativa). We opted to use the name full otherness, instead of absolute otherness, in order to refer to ourselves, to our interior as something that is full like the essence of the "other", but bearing in mind how it differs from and is similar to the "self".

6 We agree with Resende (2009, p. 32) when he says: "[...] the meeting that Ricoeur alludes to occurs in the gaps, in the spaces where discourse is produced. This form of understanding the exercise of language somewhat contradicts what is seen as dominant in the initial stages of media studies, revealing how much communication depends on both the world we live and the world we read, as seen by Ricoeur (1994). By discussing the tessiture of the plot, he sets out the narrative in a triple mimesis, which restores the relationship between the world of the author, the text and the reader" The work which Resende is referring to here is "Time and the narrative", volume 1, indicated in our bibliography as Ricoeur, 2010. 


\section{REFERENCES}

Abbagnano, N. (1998). Dicionário de Filosofia. (2nd ed.). São Paulo, Brazil: Martins Fontes.

Arendt, H. (2009). La condición humana. Buenos Aires, Argentina: Paidós.

Bakhtin, M. (2004). Marxismo e filosofia da linguagem. (10th ed.). São Paulo, Brazil: Hucitec.

Barbosa, F. C. (2008). Jornalismo potencializador e as formas de narrar o Outro: a alteridade brasileira no New York Times. Dissertação de mestrado em Comunicação, PUC-Rio, Rio de Janeiro.

Benetti, M. (2007). Análise do Discurso: estudo de vozes e sentidos. In: LACO, C.; BENETTI, M. (Eds.). Metodologia de pesquisa em jornalismo, (pp. 107-122). Petrópolis, Brazil: Vozes.

Benetti, M. (2008). O jornalismo como gênero discursivo. Galáxia, (14), $13-28$.

Benetti, M.; Freitas, C. (2015). A fenomenologia da memória e o "homem capaz" do jornalismo. Conexão - Comunicação e Cultura, 14(28), 167-185.

Bubant, N.; Willerslev, R. (2014). The dark side of empathy: mimesis, deception and the magic of alterity. Comparative Study of Society and History, 54(1), 5-34.

Buber, M. (1986). I and Thou. Gloucester, UK: Peter Smith Publisher.

Charaudeau, P. (1991). La communication et le droit à la paorole dans une interaction du même et de l'auttre. Cahiers de Praxématique, (17), 27-47.

Charaudeau, P. (2013). Discurso das mídias. (2nd ed.). São Paulo, Brazil: Contexto.

Cornu, D. (1999). Jornalismo e verdade: para uma ética da informação. Lisboa, Portugal: Instituto Piaget.

Costa, C. C. B. (2010). A TV, o Outro e o Mesmo: figuras da alteridade e traços identitários no Jornal Hoje da Rede Globo. Dissertação de mestrado em Cultura e Sociedade, UFBA, Salvador.

Dionizio, P. M. (2011). Entre mundos: um encontro com o outro na tessitura da narrativa jornalística. Dissertação de mestrado em Comunicação, UFMG, Belo Horizonte.

Ferreira, A. G. (1960). Dicionário de latim-português. Porto, Portugal: Porto.

Foessel, M. (2016). The world of the text and the world of life: two con- 
tradictory paradigms? In: Davidson, S.; Vallé, M.-A. (Eds.). Hermeneutics and Phenomenology in Paul Ricoeur: between text and phenomenon, (pp. 75-86). Basel, Switzerland: Springer.

Genette, G. (1995). Discurso da narrativa. Lisboa, Portugal: Vega.

Genro Filho, A. (1987). O segredo da pirâmide: para uma teoria marxista do jornalismo. Porto Alegre, Brazil: Tchê!.

Gomes, I. (2012). Olhares sobre o outro: estudo das representações do Islã nos jornais Estado de S.Paulo e Folha de S. Paulo. Tese de doutorado em Comunicação, UMESP, São Bernardo do Campo.

Hazell, C. (2009). Alterity: the experience of the other. Bloomington, USA: Author House.

Husserl, E. (1982). Cartesian meditations: an introduction to Phenomenology. Boston, USA: Martinos Nijhoff Publishers.

Jodelet, D. (1998). A alteridade como produto e processo psicossocial. In: ARRUDA, A. (Ed.). Representando a alteridade, (pp. 47-67). Petrópolis, Brazil: Vozes.

Karam, F. (1997). Jornalismo, ética e liberdade. São Paulo, Brazil: Summus.

Lago, C. (2014). Ensinamentos antropológicos: a possibilidade de apreensão do "outro" no jornalismo. Brazilian Journalism Research, 11 (2), 172 187.

Lévinas, E. (1971). Totalité et infini: essai sur l'exteriorité. Hague, Netherlands: Kluwer Academic.

Lévinas, E. (1982). Ética e infinito. Lisboa, Portugal: Edições 70.

Lévinas, E. (1987). De otro modo que ser, o más allá de la esencia. Salamanca, Spain: Ediciones Sígueme.

Lévinas, E. (1999). Alterity and transcendence. Londres, Inglaterra: The Athlone Press.

Lévinas, E. (2010). Entre nós: ensaios sobre alteridade. Petrópolis, Brazil: Vozes.

Marcondes Filho, C. (2016). Alterity, machines and Eros: a new vision of communication as an event. In: Gunkel, D. J.; Marcondes Filho, C.; Mersch, D. (Eds.). The changing face of alterity: communication, technology, and other subjects, (pp. 89-102). New York, USA: Rowman \& Littlefield International.

Martino, L. M. S. (2016). Epistemologia da alteridade: entre explicar e compreender outrem. Líbero, 19(37), 101-108. 
Meditsch, E. (2001). Gêneros de discurso, conhecimento, intersubjetividade, argumentação: ferramentas para uma aproximação à fisiologia normal do jornalismo. Anais do X Encontro da Compós, Brasília: Compós.

Merleau-Ponty, M. (1968). La structure du comportement. (6th ed.). Paris, France: Presses Universitaires de France.

Merleau-Ponty, M. (2011). Fenomenologia da percepção. (4th ed.). São Paulo, Brazil: Martins Fontes.

Motta, L. G. (2013). Análise crítica da narrativa. Brasília, Brazil: Editora da UnB.

Nussbaum, M. (2001). Upheavals of thought: the intelligence of emotions. Cambridge, UK: Cambridge University Press. Tradução nossa.

Peres, A. C. (2016). Narrar o outro: notas sobre a centralidade do testemunho para as narrativas jornalísticas. Galáxia, (31), 92-104.

Prado, J. L. A.; Bairon, S. (2007). A invenção do Outro na mídia semanal. In: Lago, C.; Benetti, M. (Eds.). Metodologia de pesquisa em jornalismo, (pp. 251-278). Petrópolis, Brazil: Vozes, 2007.

Quicherat, L.; Saraiva, F. R. (1927). Novíssimo diccionario latino-portuguez. (1 la ed.). Rio de Janeiro, Brazil: Garnier.

Reginato, G. D. (2016). As finalidades do jornalismo: o que dizem veículos, jornalistas e leitores. PhD Dissertation in Communication and Information, UFRGS, Porto Alegre.

Resende, F. (2009). O jornalismo e suas narrativas: as brechas do discurso e as possibilidades do encontro. Galáxia, (18), pp. 31-43.

Resende, F. (2011). Às desordens e aos sentidos: a narrativa como problema de pesquisa. In: Silva, G. et al (Eds.). Jornalismo contemporâneo: figurações, impasses e perspectivas, (pp. 119-138). Salvador, Brasil: EDUFBA; Brasília, Brazil: Compós.

Resende, F. (2014). Representação das diferenças no discurso jornalístico. Brazilian Journalism Research, 10, pp. 59-76.

Ricoeur, P. (1986). Du texte à l'action: Essais d'herméneutique II. Paris, France: Le Seuil.

Ricoeur, P. (2006). Percurso do reconhecimento. São Paulo, Brazil: Loyola.

Ricoeur, P. (2008). O Justo I: a justiça como regra moral e instituição. São Paulo, Brazil: Martins Fontes.

Ricoeur, P. (2010). Tempo e narrativa. Tomo I. São Paulo, Brazil: Martins Fontes.

Ricoeur, P. (2014). O si-mesmo como outro. São Paulo, Brazil: Martins Fontes. 
Ricoeur, P. (2015). Memory, history, oblivion. In: Kearney, R.; Treanor, B. (Eds.). Carnal hermeneutics, (pp. 148-156). Nova York, USA: Fordham University Press.

Romdenh-Romluc, K. (2011). Merleau-Ponty and phenomenology of perception. Nova York, USA: Routledge.

Sodré, O. (2007). Percurso filosófico para a concepção de alteridade. Síntese, 34(109), 157-184.

Traquina, N. (2012). Teorias do jornalismo: por que as notícias são como são. V.1. Florianópolis, Brazil: Insular.

Treanor, B. (2006). Aspects of alterity: Lévinas, Marcel, and the contemporary debate. Nova York, USA: Fordham University Press.

Wispé, L. (1986). The distinction between sympathy and empathy: to call forth a concept, a word is needed. Journal of Personality and Social Psychology, 50(2), pp. 314-321.

Camila Freitas has a Master's in Communication and Information from the Post-Graduate Programme in Communication and Information (PPGCOM) at the Rio Grande do Sul Federal University Sul (UFRGS). She is a member of the Journalism Research Center (Nupejor) - UFRGS/CNPq. E-mail: freitas.csiqueira@gmail.com

Márcia Benetti has a doctorate in Communication from Pontifícia Catholic University in São Paulo (PUCSP). She is a professor at the Rio Grande do Sul Federal University (UFRCS) and is a member of the Post-Graduate Programme in Communication and Information. She is a researcher at CNPq and a coordinator at the Journalism Research Center (Nupejor) - UFRCS/CNPq. E-mail: marcia.benetti@gmail.com 